\title{
THE STAKEHOLDER ANALYSIS FOR FISHERIES MANAGEMENT
}

\author{
Suharno $^{1 *}$, Agus Arifin ${ }^{2}$, and Ary Yunanto ${ }^{3}$ \\ ${ }^{1}$ Economics and Development Studies, Faculty of Economics and Business, Jenderal Soedirman \\ University \\ ${ }^{2}$ Economics and Development Studies, Faculty of Economics and Business, Jendera*1 Soedirman \\ University \\ ${ }^{3}$ Management Department, Faculty of Economics and Business, Jenderal Soedirman University
}

\begin{abstract}
The south sea of Central Java as a fishing ground for south coast fishers makes its resources common-pool resources, and the utilization of ownership rights becomes unclear. As a result, fisheries resources experience excessive utilization, which indicates the phenomenon of the tragedy of the common. Based on these conditions, appropriate rules and policies are needed in the institutional management of fisheries resources to remain sustainable. The purpose of this study is: to identify the roles of stakeholders in fisheries management. The analysis used is stakeholder analysis. The results of the study show that: Stakeholder groups involved in fisheries management are subjects, bystanders, actors, and players.
\end{abstract}

\section{INTRODUCTION}

Causes of failure of fisheries resource management due to complex problems. Emerging fisheries problems are usually multi-sector and various aspects such as ecology, economy, social, ethics, and management (Suharno et al., 2019). Campbell et al. (2012) suggested that the effectiveness of the watershed is highly dependent on each relevant stakeholder to submit and obey existing rules. According to Salayo et al. (2006), Merino et al. (2008) conflicts that often occur in the use of fisheries resources, because they have two different objectives, namely for the purpose of protecting fisheries resource ecosystems and ecological processes, and another aim is to exploit fisheries resources used in meeting economic needs and welfare of the population. Further conflicts that develop are conflicts of interest between sectors and between agencies involved in watershed management and conservation (Irnawati et al. 2013, Tampubolon and Satria 2013).

Fisheries management is an obligation mandated by Law No. 31/2004 and Law No. $45 / 2009$ concerning fisheries. Fisheries management is defined as all efforts, including integrated processes in information gathering, analysis, planning, consultation, decision

* Corresponding author : $\underline{\text { suharno@unsoed.ac.id }}$ 
making, allocation of fish resources, and implementation and law enforcement of laws and regulations in the field of fisheries, carried out by the government or authority others that are directed at achieving the sustainability of the productivity of aquatic biological resources and agreed objectives.

Since the implementation of decentralization in Indonesia has implications for natural resource management, it is the active participation of local communities in the process of managing the area. Until now, the role of the community in the management of fisheries resources is still very limited as a subject in activities. It is still necessary to develop partnership relationships between stakeholders based on the concept of mutual need relationships and equality, sustainable and mutually beneficial relations. Some of the negative impacts of development activities are still found, for example, the emergence of elimination of communal rights, environmental degradation, the lack of rights of local communities to access public needs, and the emphasis on political bargaining positions.

The problem of this research is that each role in the overall fisheries management has not been identified. Community-based fisheries resource management that is suitable to be applied today is accommodating community involvement in fisheries resource management based on participatory fisheries / co-management, Pomeroy and Williams, (1994) mentioning a central element of co-management is a partnership between government, society, and users other resources. Implementing co-management as a joint management concept means that various stakeholders (stakeholders) agree to share roles in management, rights, and responsibilities, over a region or natural resource as intended by the main goal so that management is more precise, efficient, fair and equitable (Susilowati, 1999; Nikijuluw, 2002). Discussion of fisheries resource management is inseparable from coastal and marine areas and stakeholders so that collaborative fisheries resource management is needed which involves small-scale fishers and stakeholders.

This condition is purified about the need for research on sustainable management of fisheries resources, especially in Cilacap waters with mapping based on parties / stakeholders so that they can accommodate the interests of various related parties, namely: protection of fisheries resources, preservation of the surrounding environment, and involving human elements that cannot be separated as social and economic beings.

\section{ANALYTICAL METHOD}

The function of fishery production is a link between the use of production input factors (fisheries as a composite index of ships/boats, fishing equipment, fuel, labor and ability to manage) with the level of production (output). A large number of fishing gear that is operated in waters and limited fishing areas will create utilization conflicts between fishers and the threat of damage to fisheries resources.

In-depth observations are needed to analyze the condition of the fishery through a study of fisheries resource management by collaborating full involving small-scale fishers and stakeholders. Current conditions for managing fisheries resources have not collaborated fully involving small-scale fishers and stakeholders. The potential of fisheries resources must be managed well by looking at the various aspects involved.

The research was carried out by directly observing the problem (by collaborating fully with fisheries management involving fishers and stakeholders) that exist and are being faced in the waters of Cilacap.

This study uses data to be collected in the form of primary data and secondary data. In general, the types of data collected from both primary and secondary data are Data on the role of fisheries stakeholders (fishers, government, and the private sector) in the management of small-scale shrimp fisheries. 
Secondary data was collected through data related to research problems obtained in the form of documents and files originating from reports of activities, books, legislation, and journals related to the management of shrimp fisheries in the waters of Cilacap and elsewhere with similar problems. Secondary data, among others, comes from Government agencies (Ministry of Marine Fisheries / MMF; Fisheries Service; Central Statistics Agency, and related agencies).

Primary data was collected by the technique of distributing questionnaires to respondents, in-depth interviews, direct observations in the field, and focus discussion groups. This data can also be in the form of references from expert opinions. Reference to expert opinion is collected from expert opinions during interviews and when opinions or ideas are conveyed through print and electronic media about a problem related to research. These experts can come from Government agencies (Ministry of Maritime Affairs / Fisheries and Fisheries Services), higher education, research institutions, and fisheries observers/practitioners. The collection of primary data through questionnaires is carried out with the stages of sampling group selection, identification/selection of respondents, and data collection to respondents.

Stakeholder analysis is needed due to the overlapping of each role whose status is not clear in the stakeholder. Reed et al. (2009) explain the stakeholder analysis model that can be described to be used as a model. Stakeholder analysis requires the following steps:

1. Identify stakeholders and their roles

2. Identify expectations for stakeholders about the program

3. Benefits-benefits / benefits that will be obtained for stakeholders

4. Categorizing and differentiating stakeholders based on their interests and influence.

\section{RESULTS AND DISCUSSIONS}

The definition of a stakeholder is a person, or group, or institution because its role can be influenced positively or negatively due to the existence of a program/project activity, or vice versa a person, or group, or institution can influence a program/project activity. Stakeholders are mapped into a matrix of stakeholder analysis according to the value of importance and influence.

The amount of interest is assessed from:

1. Stakeholder involvement in fisheries management

2. Reliance of stakeholders on fisheries management

3. The role of each stakeholder related to fisheries management

4. Benefits obtained by stakeholders from fisheries management

5. Stakeholders' interests in sustainable fisheries management

The amount of influence is assessed from:

1. Instruments and sources of strength (power) at each stakeholder

2. Position of the degree of stakeholders in decision making

3. HR support for the management of fisheries resources

4. Funding and management capabilities for fisheries resource management

5. Interaction with other stakeholders

Assessment of the importance and influence of stakeholders using the Likert scale, namely the value of 4: very high, 3: high, 2: sufficient, 1: less, 0: low. The amount of value obtained by each stakeholder is a point for the magnitude of interest and points for the magnitude of influence. After knowing the value of importance and influence, each stakeholder is mapped into a matrix of interests and influences using Mactor software.

Data retrieval is done by direct interviews and questionnaire to representatives of each party identified from the results of actor analysis, processing qualitative data from interview results is quantified by referring to tiered data measurements. 
Sustainable shrimp fisheries management in Cilacap waters has several stakeholders involved in its management. Stakeholder analysis is carried out to identify and map actors (level of importance and influence) in the management of sustainable shrimp fisheries in Cilacap waters. Based on the results of interviews and deepening, 11 stakeholders were involved in the management of shrimp fisheries. In Table 1. a profile of the roles of each stakeholder involved is presented.

Table 1. Stakeholders for Sustainable Fisheries Management in Cilacap Waters

\begin{tabular}{|c|c|c|}
\hline No & Stakeholders & Role \\
\hline 1 & $\begin{array}{l}\text { Fisheries \& Marine Services } \\
\text { (District and Province) }\end{array}$ & $\begin{array}{l}\text { Regional authorities that protect the } \\
\text { integrity of their territory, improve the } \\
\text { welfare of the local community, \& } \\
\text { preserve the environment of their area }\end{array}$ \\
\hline 2 & $\begin{array}{l}\text { Indonesian Fishermen } \\
\text { Association of Cilacap }\end{array}$ & $\begin{array}{l}\text { Community activity groups that participate in } \\
\text { fisheries management together with fishers and } \\
\text { fishing communities }\end{array}$ \\
\hline 3 & Non-governmental organization & $\begin{array}{l}\text { Community activity groups that control the } \\
\text { compliance of rules and local wisdom in the } \\
\text { local environment }\end{array}$ \\
\hline 4 & Unsoed & $\begin{array}{l}\text { Educational institutions, community } \\
\text { practitioner groups, academics, researchers, } \\
\text { observers in fisheries management }\end{array}$ \\
\hline 5 & Cilacap Fisheries Association & $\begin{array}{l}\text { Community activity group that connects } \\
\text { fishers with other related parties }\end{array}$ \\
\hline 6 & Traders & $\begin{array}{l}\text { Supplier group of fishermen's goods and } \\
\text { services, \& users of fishermen's catch products }\end{array}$ \\
\hline 7 & Village & $\begin{array}{l}\text { Village authorities that have the authority to } \\
\text { regulate, serve, and manage the rights and } \\
\text { obligations of citizens in their administrative } \\
\text { areas }\end{array}$ \\
\hline 8 & KUD Minosaroyo & $\begin{array}{l}\text { Fisheries goods and services supplier group, } \\
\& \text { fish auction process authority at Fish } \\
\text { Auction Place }\end{array}$ \\
\hline 9 & Local Community & $\begin{array}{l}\text { Community groups in various groups: age } \\
\text { not yet productive, productive age and } \\
\text { unproductive age }\end{array}$ \\
\hline 10 & $\begin{array}{l}\text { Ministry of Maritime Affairs and } \\
\text { Fisheries }\end{array}$ & National fisheries concession authority \\
\hline 11 & Fishers & $\begin{array}{l}\text { Groups that have the skills and knowledge to } \\
\text { run operational fisheries management }\end{array}$ \\
\hline
\end{tabular}

Source: Primary Data Processed, 2019.

In order to manage fisheries resources, several objectives must be determined that is related to all stakeholders. The objectives to be achieved are, 1. sustainable shrimp fisheries production, 2. increasing fisherman income, and 3. increasing fisherman catches.

After knowing the role of each party, then categorize stakeholders based on their interests and influence. Stakeholders are mapped into stakeholder analysis matrices based on their importance and influence.

Assessment of the importance and influence of stakeholders using Likert scale is value 4: very high, 3: high, 2: enough, 1: less high, 0 : low. An assessment of the magnitude of 
stakeholder interests in the management of shrimp fisheries in Cilacap waters can be seen in Table. 2.

Table 2.

Assessment of Stakeholder Interests

\begin{tabular}{|c|c|c|c|c|c|c|c|c|c|c|c|}
\hline MDI Criteria & 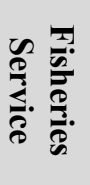 & $\underset{\pi}{\mathscr{a}}$ & Oֵ & 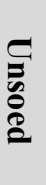 & 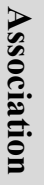 & 承 & 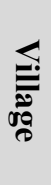 & 즐 & 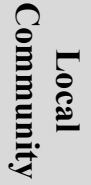 & 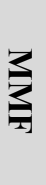 & $\frac{3}{\frac{\pi}{6}}$ \\
\hline Fisheries Service & 0 & 3 & 1 & 1 & 3 & 3 & 1 & 3 & 1 & 3 & 4 \\
\hline HNSI & 1 & 0 & 3 & 1 & 3 & 3 & 1 & 3 & 1 & 3 & 3 \\
\hline NGO & 1 & 1 & 0 & 1 & 1 & 1 & 1 & 1 & 1 & 1 & 1 \\
\hline Unsoed & 1 & 1 & 1 & 0 & 1 & 1 & 1 & 1 & 1 & 1 & 1 \\
\hline Association & 1 & 2 & 1 & 1 & 0 & 1 & 1 & 2 & 1 & 1 & 2 \\
\hline Traders & 1 & 1 & 1 & 1 & 1 & 0 & 1 & 1 & 2 & 2 & 2 \\
\hline Village & 2 & 2 & 2 & 2 & 2 & 2 & 0 & 2 & 2 & 2 & 2 \\
\hline KUD & 2 & 1 & 1 & 1 & 3 & 3 & 2 & 0 & 3 & 3 & 3 \\
\hline Local Community & 1 & 1 & 1 & 1 & 1 & 1 & 1 & 1 & 0 & 1 & 1 \\
\hline MMF & 3 & 2 & 1 & 1 & 2 & 1 & 1 & 1 & 1 & 0 & 3 \\
\hline Fishers & 3 & 1 & 1 & 1 & 2 & 1 & 1 & 2 & 2 & 2 & 0 \\
\hline
\end{tabular}

Source: Primary Data Processed with Mactor Software, 2019.

Assessment of the importance and influence of stakeholders based on the objectives to be achieved using a Likert scale, namely the value of +4 or -4 : very high, +3 or -3 : high,+2 or -2 : enough, +1 or -1 : less high, 0 : low. Assessing the magnitude of stakeholder interests by basing their objectives on the management of shrimp fisheries in Cilacap waters can be seen in Table 3.

Table 3.

Assessment of Stakeholder Interests based on Purpose

\begin{tabular}{lccc}
\hline \multicolumn{1}{c}{ 2MAO Criteria } & $\begin{array}{c}\text { Sustainable } \\
\text { Fisheries } \\
\text { Production }\end{array}$ & $\begin{array}{c}\text { Increase in } \\
\text { Fishers's Income }\end{array}$ & $\begin{array}{c}\text { Increase in Fishers's } \\
\text { Catches }\end{array}$ \\
\hline Fisheries Service & 3 & 3 & 3 \\
HNSI & 2 & 3 & 3 \\
NGO & 1 & 1 & 1 \\
Unsoed & 1 & 1 & 1 \\
Association & -1 & 2 & 2 \\
Traders & -1 & 1 & 1 \\
Village & 2 & 2 & 1 \\
KUD & -1 & 1 & 1 \\
Local Community & -1 & 1 & 3 \\
MMF & 3 & 3 & 3 \\
Fishers & -2 & 3 & \\
\hline
\end{tabular}

Source: Primary Data Processed with Mactor Software, 2019.

After identification, we are mapping the interests and influence of stakeholders in fisheries management in the waters of Cilacap, then mapping into the stakeholder grid analysis matrix. This matrix consists of 4 quadrants, namely spectators (Spectator), Actors (Actors), Subjects (Subject) and Players (Player), the position of each stakeholder will be mapped according to the results of the assessment of importance and influence. 
Based on the stakeholder grid analysis in Figure 1. it was found that the fisheries service, KUD Minosaroyo, Ministry of Maritime Affairs and Fisheries, and fishers were in the position of players (player). The Cilacap district fisheries office and the Central Java fisheries department get a mandate to manage sustainable fisheries activities which are commanded by the Ministry of Fisheries and Marine Affairs. The conditions in its operation, fisheries management in Cilacap also involved the KUD Minosaroyo and fishers to share their roles in carrying out their activities.

Villages and HNSI have the role as subject (subject) having a high enough interest in fisheries management in Cilacap waters, while the influence they have is not as big as their interests. Village and HNSI as social control of the operation of fisheries management following applicable rules, the orderliness of the social environment of the community, and the need for local labor. The welfare of the community and fishers, improving the quality of life (religion, education, health, public facilities, culture), the orderliness of the social environment of the community are closely related to sustainability in fisheries management. Villages and HNSI can shift their roles into players by increasing their influence, especially in interacting with other stakeholders, which have been weak, considering that other influences are difficult to improve.

Local communities, associations, and traders are at the position as an actor. Local communities, associations, and traders have a high interest in fisheries management in Cilacap waters, in this case, related to the availability of shrimp supply, fluctuations in fisheries commodity prices and selectivity rules for fishing gear.

Unsoed and NGOs have the lowest interests because it is more coordination, not executor or policymaker. Unsoed and NGOs have influence in coordination and policymaking in fisheries management.

Figure 1.

Assessment of Stakeholder Interests 


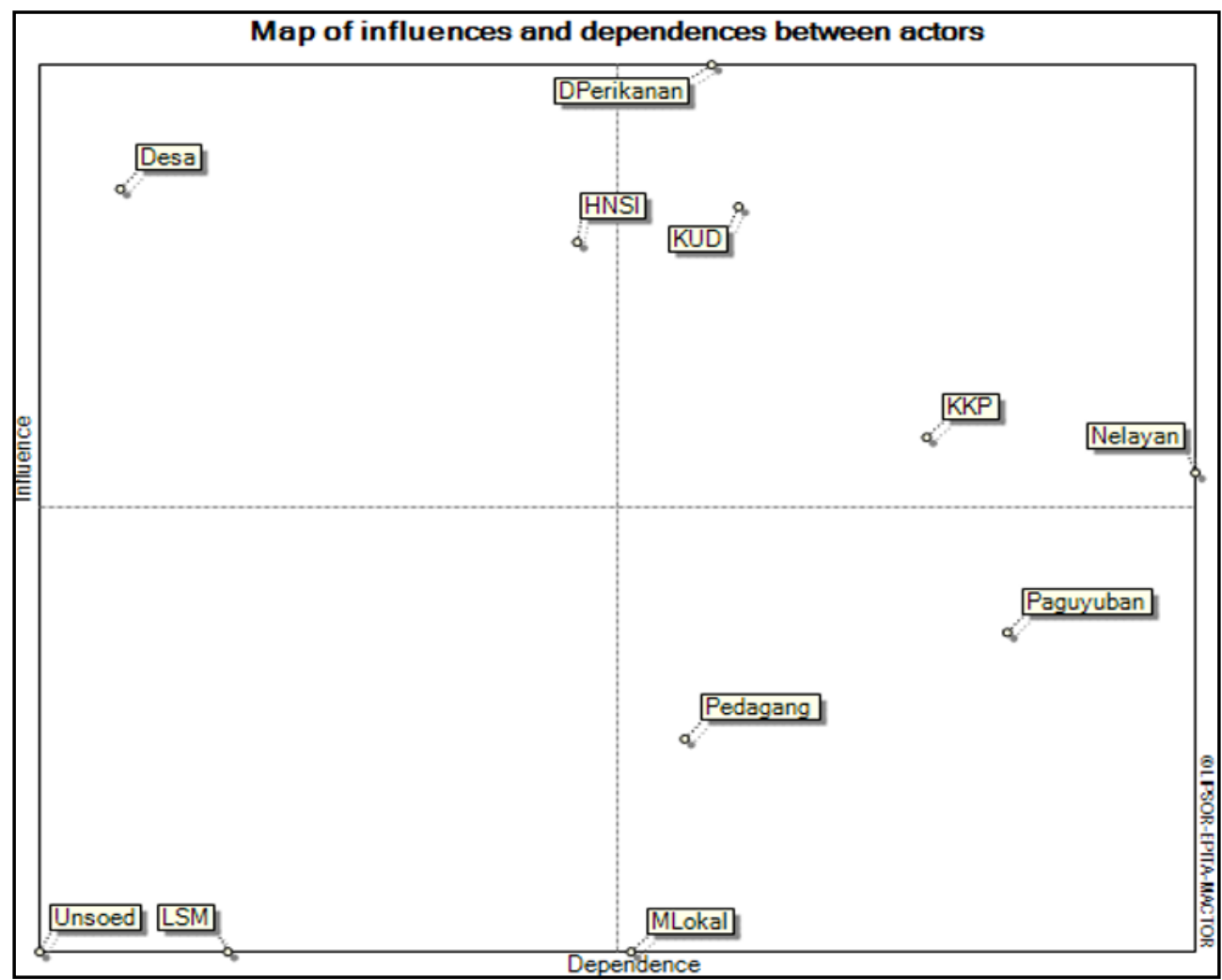

Source: Primary Data Processed with Mactor Software, 2019.

\section{CONCLUSION AND IMPLICATIONS}

The result of the analysis of the choice of shrimp resource management in Cilacap waters from key-persons is cooperative co-management management that is through the initial exchange of information, the views of the community begin to be included in the agenda and issues as input in the management of fisheries resources, based on:

The findings of the stakeholders' analysis show: fisheries service, KUD Minosaroyo, Ministry of Maritime Affairs and Fisheries, and fishermen as key players / players in managing Cilacap fisheries; Villages and HNSI act as subjects; Local communities, associations and traders in positions as actors; while Unsoed and NGOs only have low roles as spectators.

This research has evaluated the roles of stakeholders in current fisheries management. Furthermore, it can be recommended by setting up a new institution that is not currently able to strengthen fisheries management and is able to run a comprehensive and collaborative fisheries management model by accommodating the existence of elements of local institutional wisdom in the fisheries sector of Cilacap Regency.

\section{BIBLIOGRAPHY}

1. Campbell, S. J. et al. Weak Compliance Undermines the Success of No-Take Zones in a Large Government-Controlled Marine Protected Area. PLoS One 7, 11 (2012). 
2. Irnawati, Ririn. et al. Teknik Interpretative Structural Modeling (ISM) Untuk Strategi Implementasi Model Pengelolaan Perikanan Tangkap Di Taman Nasional Karimunjawa. Jurnal Ilmu Pertanian dan Perikanan. 2 (1), 75-86 (2013).

3. Merino, G., Morales-Nin, B., Maynou, F. \& Grau, A. M. Assessment and bioeconomic analysis of the Majorca (NW Mediterranean) trammel net fishery. Aquat. Living Resour. (22), 75-56 (2008) .

4. Bambang, S. \& Bowo, F. Dosen Fak. Hukum Universitas Wahid Hasyim Alumni MIH UNDIP Nikijuluw, V.P.H. 2002. Rezim Pengelolaan Sumberdaya Perikanan . Jurnal Ilmiah Ilmu Hukum QISTI 38. J. Ilm. Ilmu Huk. Qisti (2002).

5. Pomeroy, R. S. \& Williams, M. J. Fisheries Co-management and Small-scale Fisheries: A Policy Brief. International Center for Living Aquatic Resources Management (1994).

6. Reed, M. S. et al. Who's in and why? A typology of stakeholder analysis methods for natural resource management. J. Environ. Manage. (90), 1943-1949 (2009).

7. Salayo, N. D., Ahmed M., Garces, L. \& Viswanathan, K. An Overview of Fisheries Conflicts in South and Southeast Asia: Recommendations, Challenges and Directions. Naga WorldFish Cent. Q. (29), 1-2 (2006).

8. Suharno, Anwar, N. \& Saraswati, E. A technique of assessing the status of sustainability of resources. in IOP Conference Series: Earth and Environmental Science (250), 1 (2019).

9. Susilowati, I. An Analysis of Co-Management Fisheries In West Sumatra Province, Indonesia: A Case Study of Ikan Larangan. Reserach Report, International Center For Living Aquatic Resource Management, Manila, Philipines. (1999). 